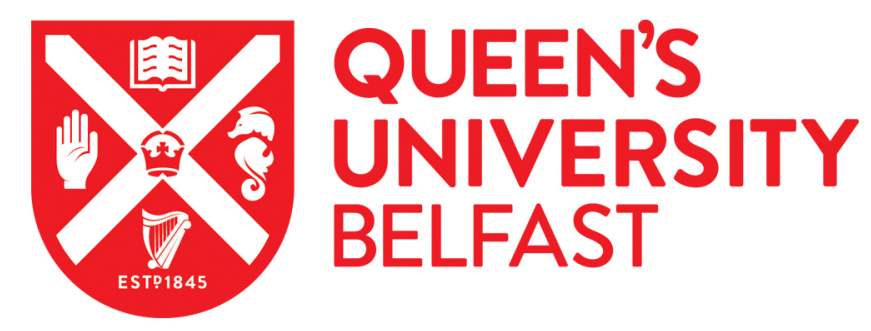

\title{
Transverse basilar cleft: Two more probable familial cases in an archaeological context
}

Tur, S. S., Svyatko, S. V., \& Rykun, M. P. (2019). Transverse basilar cleft: Two more probable familial cases in an archaeological context. International Journal of Osteoarchaeology, 29(1), 144-148.

https://doi.org/10.1002/oa.2692

Published in:

International Journal of Osteoarchaeology

Document Version:

Peer reviewed version

Queen's University Belfast - Research Portal:

Link to publication record in Queen's University Belfast Research Portal

Publisher rights

(c) 2018 John Wiley \& Sons, Ltd

This work is made available online in accordance with the publisher's policies. Please refer to any applicable terms of use of the publisher.

\section{General rights}

Copyright for the publications made accessible via the Queen's University Belfast Research Portal is retained by the author(s) and / or other copyright owners and it is a condition of accessing these publications that users recognise and abide by the legal requirements associated with these rights.

Take down policy

The Research Portal is Queen's institutional repository that provides access to Queen's research output. Every effort has been made to ensure that content in the Research Portal does not infringe any person's rights, or applicable UK laws. If you discover content in the Research Portal that you believe breaches copyright or violates any law, please contact openaccess@qub.ac.uk. 
Transverse basilar cleft: two more probable familial cases in an archaeological context Running title: Transverse basilar cleft: probable familial cases

\title{
S.S. TUR ${ }^{a}$, S.V. SVYATKO ${ }^{b *}$ AND M.P. RYKUN ${ }^{c}$
}

${ }^{a}$ Museum of Archaeology and Ethnography of Altai, Altai State University, Barnaul, Russia

b ${ }^{14}$ CHRONO Centre for Climate, the Environment, and Chronology; Queen's University of Belfast, Northern Ireland, UK

${ }^{c}$ Cabinet of Anthropology, Tomsk State University, Tomsk, Russia

* Correspondence to: Dr Svetlana Svyatko, 14CHRONO Centre for Climate, the Environment, and Chronology; Queen's University of Belfast, Belfast BT7 1NN, Northern Ireland, UK.

E-mail: s.svyatko@qub.ac.uk

\begin{abstract}
Transverse basilar cleft (TBC) is a very rare congenital anomaly representing a coronal fissure completely or partially intersecting the basioccipital at the level of the pharyngeal tubercle. It is usually asymptomatic, but can sometimes be part of a syndrome. Population frequencies of this anomaly are no more than $1 \%$, with few exceptions. Two skulls with TBC were found in the Ayrydash 1 cemetery of Altai Mountains nomads, Russia, attributed to the Hunno-Sarmatian period $\left(2^{\text {nd }} \mathrm{c}\right.$. $\mathrm{BC}-5^{\text {th }} \mathrm{c}$. $\left.\mathrm{AD}\right)$. In this paper, we test the possibility of a familial relationship between the individuals who shared by this condition, using the Alt and Vach method for nonspatial analysis of skeletal kinship based on cranial and dental non-metric traits. Results of the study show that the frequency of TBC is significantly higher in the Ayrydash 1 sample than in the rest of the skeletal population from the Hunno-Sarmatian period $(p<0.05)$. This suggests that the individuals affected by TBC were most likely genetic relatives. The observed clustering of $\mathrm{TBC}$ and some other rare anomalies within local groups of Altai Mountains nomads appears to be due to parental consanguinity in their community.
\end{abstract}

Key words: Altai, cranial congenital anomalies, Hunno-Sarmatian period, kinship analysis, proatlas, transverse basilar cleft.

\section{Introduction}

The craniovertebral junction $(\mathrm{CVJ})$ is a phylogenetically and ontogenetically unstable region of the axial skeleton, in which numerous anatomical variants, anomalies and malformations can occur (Schmorl, Junghanns, 1971). The most common of these are manifestations of the proatlas and assimilation of the atlas into the basiocciput. In embryogenesis, the basiocciput is formed from amalgamation of the first four sclerotomes, three of which have merged at an earlier stage. The fourth develops as a transitional vertebra (Müller \& O'Rahilly, 2003) called the proatlas, because in lower vertebrates, including reptiles and dinosaurs, it remains as an independent element (Hayek, 1924; Jenkins, 1971). The proatlas forms the anterior margin of the foramen magnum and the occipital condyles. Its failure to integrate with other occipital sclerotomes can result in such anomalies as precondylar tubercle, third occipital condyle, hypochondral arch, paracondylar process, hypoglossal canal bridging, or transverse basilar cleft (Prescher, 1997). The latter represents a coronal fissure partially or completely intersecting the basioccipital at the level of the pharyngeal tubercle (Figure 1). This anomaly is very rare in clinical and skeletal samples. Clinically, transverse basilar cleft (TBC) is usually asymptomatic (Lombardi, 1961; Schmidt et al., 1978; Johnson \& Israel, 1979), however, 
it sometimes appears as a part of syndromes (List, 1941; Johnson \& Israel, 1979; Woon et al., 1980; Whitehead et al., 2015; Mahdi \& Whitehead, 2017).

In archaeological contexts, rare congenital anomalies can be useful for identifying closely related individuals within a site (Alt \& Vach, 1992; Case et al., 2017). As a familial trait, TBC has been described in two full-term fetuses from a tomb in medieval Apulia, Italy (Anderson, 2000). In this paper, we test whether two adult individuals showing this anomaly from a single burial site in Altai, Russia, attributed to the Hunno-Sarmatian period, could be genetic relatives.

\section{Materials and Methods}

In total, more than 650 skulls of adults and children from burial sites in the Altai Mountains have been examined. The remains belong to nomads of the Pazyryk Culture from the Scythian period $\left(5^{\text {th }}-3^{\text {rd }}\right.$ c. BC) and the Bulan-Koba Culture from the Hunno-Sarmatian period $\left(2^{\text {nd }}\right.$ c. $\mathrm{BC}-5^{\text {th }}$ c. $\left.A D\right)$.

Transverse basilar cleft was visually scored as present, absent, or, when the basioccipital was missing/severely damaged, as unscorable. The trait was recorded as present at any degree of expression. Frequency of this anomaly was calculated as the ratio of the number of skulls with the defect, to the total number of scorable ones.

Two cases of TBC were found among skulls from the Bulan-Koba burial site of Ayrydash 1 dated to the second half of the $3^{\text {rd }}$ - the end of the $4^{\text {th }}$ c. AD (Seregin \& Matrenin, 2014; Figure 2). This cemetery has been completely excavated. The graves were clustered in groups of several rows orientated from north-west to south-east. The majority of burials were single inhumations (Soenov, 2003). Graves \#38 and \#108, in which the individuals affected by TBC were buried, were located in different sectors of the cemetery. There were no local distinctions in the burial rite within the site. Both skulls with TBC were damaged, the postcranial skeletons were unavailable for the study. Sex and age of the individuals were determined using standard osteological methods (Alekseev \& Debec, 1964; Buikstra \& Ubelaker, 1994). Sexual dimorphic cranial features, including the supraorbital ridge/glabella, supraorbital margins, slope of forehead, inion protuberance, nuchal crest, mastoid processes, mental eminence, mandibular ramuses, were estimated, taking into account their overall variability within the general population of Altai from the Hunno-Sarmatian period.

The Alt and Vach (1992) method for non-spatial analysis of skeletal kinship based on cranial and dental non-metric traits was applied, by comparing frequency of TBC in Ayrydash 1 $(n=59)$ to that from a reference sample. The reference sample consisted of 293 skulls from other Bulan-Koba burial sites. Statistical testing for frequency differences between these samples was conducted using Fisher's Exact Test.

\section{Results}

Both individuals died at a mature age. Skull from grave \#38 was determined with confidence as female. Skull from grave \#108 exhibits controversial combination of sexual dimorphic features, in which, however, feminine ones prevail.

In both skulls, the basioccipital is divided by coronal lateral fissures into two portions, anterior and posterior, which are connected only by a median bridge. In one of them, the bridge was broken post-mortem, and the portion of the basioccipital between the coronal fissures and sphenobasilar symphysis was lost [Figure 3(A)-3(B)].

The frequencies of TBC are 3.4\% (2/59) and 0\% (0/293) in Ayrydash 1 and the reference sample, respectively. The difference between them is statistically significant at the $5 \%$ level $(p=0.028)$. In the general Bulan-Koba population, including individuals from all cemeteries studied, the frequency of TBC is $0.6 \%$ (2/352). In the Pazyryk population this congenital trait has not been found $(0 / 214)$.

The statistically significant difference in the frequency of TBC between Ayrydash 1 and the Bulan-Koba reference sample indicates that random clustering of these anomalies in one 
cemetery is unlikely. As such, the two individuals with TBC buried in Ayrydash 1 apparently were genetic relatives.

\section{Discussion}

As $\mathrm{TBC}$ is a very rare and usually asymptomatic anomaly, its etiology and pathogenesis are not known.

The first evidence that there appears to be a genetic component in this condition was archaeologically derived from medieval Apulia, Italy, where familial burial practices are known to be common. It was found that two full-term fetuses affected by identical TBC were buried together in the same small tomb (Anderson, 2000).

The phenotypic spectrum of TBC varies from a little gap in one of the lateral sides to complete coronal separation of the basioccipital into two parts. On the inferior surface of the basioccipital, there are sometimes transverse or inclined bilateral ridges on either side of the pharyngeal tubercle, called the crista sinostosica by Mingazzini (1891), which appear to mark the fusion of the proatlas with the remainder of the basioccipital [ibid.; Figure (3C)]. Analysis of the literature data shows that the most common manifestation of TBC is an incomplete bilateral form, which appears twice as often as a unilateral form (39:17). The left side is affected more frequently in the unilateral forms (13:3), and possibly more severely in the incomplete bilateral forms. A complete TBC occurs in about $10 \%$ of all TBC cases.

Transverse basilar cleft is often associated with other anomalies of the skull including assimilation of the atlas into the basiocciput (Morselli, 1890; List, 1941; Lombardi, 1961), premature synostoses of the cranial sutures (Schultz, 1929; Limson, 1932; Kruyff, 1967; Woon et al., 1980), choanal atresia, and occurrence of a third condyle (Barth, 1896; Schultz, 1929; Johnson \& Israel, 1979). None of the listed features, however, are present in the skulls from Ayrydash 1. Transverse basilar cleft can also be a part of severe syndromes such as Cornelia de Lange (Whitehead et al., 2015), CHARGE (Mahdi \& Whitehead, 2017), Arnold-Chiari (List, 1941), as well as some others (Le Double, 1903; Johnson \& Israel, 1979; Woon et al., 1980). In syndromic cases of TBC, infants have reduced chances of survival into adulthood. From a clinical practice perspective (Woon et al., 1980), above two full-term fetuses with TBC buried in a familial tomb in medieval Italy (Anderson, 2000) are likely to be twins affected by a syndromic disease. Pathological traits, which would be indicative of a syndrome, have not been found in the skulls from Ayrydash 1.

Although more than 70 cases of TBC have been reported in the anatomical, clinical and bioarchaeological literature, there are very few population-based studies (Table 1). In the majority of the recorded archaeological groups, the frequency of this anomaly is less than $1 \%$. Only in the Jomon population, Japan, does it reach 6\%. Transverse basilar cleft cases of different degrees of expression have been found in skeletal samples from six local sites of the Middle to Final Jomon period (Kawakubo et al, 2014). Results from studies of dental, craniometric and molecular data suggest that the origin of Jomonese people traces back to the indigenous inhabitants of Southeast Asia (Hanihara, 1993). In this regard, it should be noted that the socalled Deep Skull from Niah Cave in Sarawak, Malaysia, one of the earliest anatomically modern human fossils in Southeast Asia, displays TBC as well (Brothwell, 1960). Increase of frequency of this anomaly within the Jomon groups, therefore, may be explained by random genetic drift in a geographically isolated and/or sparsely populated region.

Judging by the number and size of burial sites, the Altai Mountains valleys were densely populated during the Scythian and Hunno-Sarmatian periods (Seregin \& Matrenin, 2014). Groups of the Pazyryk and Bulan-Koba Cultures are similar craniometrically, which suggests biological continuity between them. This is especially evident for females (Chikisheva \& Pozdnyakov 2000). However, there was aggregation of rare traits within some local burial sites of the Bulan-Koba Culture. Besides two cases of TBC in Ayrydash 1, three cases of premature cranial synostosis and three cases of internal frontal hyperostosis have been found in the Bulan- 
Koba 4 and Ust'-Edigan cemeteries, respectively (S. Tur, unpublished data), which may be interpreted as evidence of parental consanguinity and inbreeding. Even today, consanguineous marriages are widely practiced in several large communities. The effect of consanguinity on the prevalence of minor and major congenital anomalies, as well as recessive and multifactorial diseases, has been documented in many clinical studies (e.g. Shawky et al., 2013). Although the two individuals with TBC buried in Ayrydash 1 were probably relatives, their graves were located in different segments of the cemetery. Since at least one of these individuals was determined as a female, this may indicate that Altai Mountains nomads during the HunnoSarmatian period practiced patrilocality, in which it was common to bury married women near their husband's family graves.

\section{Conclusions}

Transverse basilar cleft is a very rare congenital anomaly characterized by a coronal fissure completely or partially intersecting the basioccipital at the level of the pharyngeal tubercle. Population frequencies of TBC are usually no more than $1 \%$, with few exceptions. Only two skulls display this anomaly in a large skeletal sample from burial sites of the Bulan-Koba Culture, Altai Mountains, attributed to the Hunno-Sarmatian period. Both findings originate from the Ayrydash 1 cemetery. The statistically significant difference in the frequency of TBC between Ayrydash 1 and the Bulan-Koba reference sample indicates that random clustering of this trait in the cemetery is rather unlikely and suggests instead a familial relationship between the individuals sharing this condition. Parental consanguinity and inbreeding could result in increased frequency of this rare anomaly in the local group of the nomads.

\section{Acknowledgements}

This work has been supported by the Russian Foundation for Basic Research (project № 16-06-00254). We thank Mr. Il'ya Chudilin for his schematic drawings made specifically for this publication and anonymous reviewers for their valuable comments and corrections which greatly improved our paper.

\section{List of figure legends}

Figure 1. Location map and plan of the Ayrydash cemetery. Marked are graves \#38 and \#108 (modified from Soenov, 2003). This figure is available in color at wileyonlinelibrary.com/journal/oa.

Figure 2. Schematic drawings, illustrating different degrees of TBC: A - a mild bilateral incomplete symmetric form, $\mathrm{B}$ - a bilateral incomplete asymmetric form, $\mathrm{C}$ - a complete cleft (modified from Lucy, 1890).

Figure 3. Transverse basilar cleft in the skulls from the Ayrydash 1 cemetery: A - from grave \#38; B - from grave \#108; C - normal variant of the basioccipital, 1 - crista synostosica (after Mingazzini, 1891), 2 - crista muscularis. This figure is available in color at wileyonlinelibrary.com/journal/oa.

\section{References}

Alekseev VP, Debec GF. 1964. Kraniometriya: Metodika antropologicheskih issledovanii. Nauka: Moskva.

Alt KW, Vach W. 1992. Non-spatial analysis of "genetic kinship" in skeletal remains. In Analyzing and Modeling Data and Knowledge: Proceedings of the 15th Annual Conference of the "Gesellschaft für Klassifikation e.V', Schader M (ed). Springer-Verlag: Berlin; 247-256. 
Anderson T. 2000. Basilar clefting: a familial condition? Annals of Anatomy 182: 583-587. DOI: 10.1016/S0940-9602(00)80110-7

Barth J. 1896. Norrønaskaller. Crania antique in parte oriental Norvegice meridionalis inventa. En studie fra Universitetets Anatomiske Institut. A.W.Broggers bogtrykkeri: Christiania.

Brothwell DR. 1960. Upper Pleistocene Human Skull from Niah Caves, Sarawak. Sarawak Museum Journal 9(15-16): 323-349.

Buikstra JE, Ubelaker DH. 1994. Standards for Data Collection from Human Skeletal Remains, Research. Series 44. Arkansas Archeological Survey: Fayetteville.

Case DT, Jones LB, Offenbecker AM. 2017. Skeletal Kinship Analysis Using Developmental Anomalies of the Foot. International Journal of Osteoarchaeology 27(2): 192-205. DOI: 10.1002/oa.252

Chikisheva TA, Pozdnyakov DV. 2000. Physical Anthropology of the Gorny Altai Populations in the Hunno-Sarmatian period. Archaeology, Ethnology and Anthropology of Eurasia 3(3): $116-131$.

Davida E. 1914. Beiträge zur Persistenz der Transitorischen Nähte. Anatomischer Anzeiger 46: $399-412$.

Hanihara T. 1993. Craniofacial Features of Southeast Asians and Jomonese: A Reconsideration of Their Microevolution Since the Late Pleistocene. Anthropological Science 101(1): 25-46. DOI: $10.1537 /$ ase. 101.25

Hayek H. 1924. Über das Schicksal des Proatlas und über die Entwicklung der Kopfgelenke bei Reptilien und Vögeln. Jahrbuch für Morphologie und mikroskopische Anatomie 53: 137-163.

Jenkins FA. 1971. The Postcranial Skeleton of African Cynodonts: Problems in the Early Evolution of the Mammalian Postcranial Skeleton. Bulletin 36, Peabody Museum of Natural History: New Haven.

Johnson GC, Israel H. 1979. Basioccipital Clefts. Radiology 133: 101-103.

Kawakubo Y, Dodo Y, Nara T., Kuraoka A. 2014. Transverse basilar cleft detected in prehistoric Jomon skulls from Japan. Anthropological Science 122(1): 45-50.

Kruyff E. 1967. Transverse Cleft in the Basi-occiput. Acta Radiologica 6: 41-48.

Le Double A-F. 1903. Traité des variations des os du crame de I'homme et de leur signification au point de vue I'Anthropologie zoologique, Vigot Fréres Éditeurs: Paris.

Limson M. 1932. Observation on the Bones of the Skull in White and Negro Fetuses and Infants. Contribution to Embryology 23(136): 207-222.

List CF. 1941. Neurologic Syndromes Accompanying Developmental Anomalies of Occipital Bone, Atlas and Axis. Archives of Neurology and Psychiatry 45(4): 577-616. DOI:10.1001/archneurpsyc.1941.02280160009001

Lombardi G. 1961. The occipital vertebra. American Journal of Roentgenology 86 (2): 260-269.

Lucy P. 1890. Les Anomalies de L'occipital Expliquées par l'anatomie comparée et le développement. Imprimerie Nouvelle: Lyon.

Mahdi E, Whitehead MT. 2017. Coronal Clival Cleft in CHARGE Syndrome. Neuroradiology Journal 30(6): 574-577. DOI: 10.1177/1971400916678248

Mingazzini G. 1891. Sul Processus Basilaris Ossis Occipitis. Anatomischer Anzeiger 14-15: 391-400.

Morselli E. 1890. Su alcune anomalie dell' osso occipitale Negli alienate. Rivista sperimentale di freniatria e di medicina legale XVI: 225-246;

Müller F, O'Rahilly R. 2003. Segmentation in Staged Human Embryos: the Occipitocervical Region Revisited. Journal of Anatomy 203:297-315.

Prescher A. 1997. The Craniocervical Junction in Man, the Osseous Variations, their Significance and Differential Diagnosis. Annals of Anatomy 179(1):1-19. DOI: 10.1016/S0940-9602(97)80126-4

Ray B, Kalthur SG, Kumar B, Bhat MRK, D'souza AS, Gulati HS, KN LK, VS B. 2014.

Morphological variations in the basioccipital region of the South Indian skull. Nepal Journal of Medical Sciences 3(2):124-128. 
Shawky RM, Elsayed SM, Zaki ME, Nour El-Din SM, Kamal FM. 2013. Consanguinity and its relevance to clinical genetics. Egyptian Journal of Medical Human Genetics 14: 157-164. DOI: $10.1016 /$ j.ejmhg.2013.01.002

Schmidt H, Sartor K, Heckl RW. 1978. Bone malformation of the craniocervical region. In Handbook of clinical neurology, Vinken PJ, Bruyn GW (eds). Elsevier: Amsterdam; 1-98.

Schmorl G, Junghanns H. 1971. The Human Spine in Health and Disease. Grune and Stratton: New York.

Schultz AH. 1929. The Metopic Fontanelle, Fissure, and Suture. American Journal of Anatomy 44(3): 484-485. DOI: 10.1002/aja.1000440306

Seregin NN, Matrenin SS. 2014. Arheologicheskie kompleksy Altaya II v. do n.e. - XI v. n.e.: istoriya issledovanii i osnovnye aspekty interpretacii. Azbuka: Barnaul.

Soenov VI. 2003. Arheologicheskie pamyatniki Gornogo Altaya gunno-sarmatskoi epohi (opisanie, sistematika, analiz). Izd-vo GAGU: Gorno-Altaisk.

Wackenheim A. 1985. Hypoplasia of the basioccipital bone and persistence of the sphenooccipital synchondrosis in a patient with transitory supplemental fissure of the basi-occipital. Neuroradiology 27: 226-231. DOI: 10.1007/BF00344493

Whitehead MT, Nagaraj UD, Pearl PL. 2015. Neuroimaging features of Cornelia de Lange syndrome. Pediatric radiology 45(8): 1198-1205. DOI: 10.1007/s00247-015-3300-5

Woon K-C, Kokich VG, Clarren SK, Cohen MM, Jr. 1980. Craniosynostosis With Associated Cranial Base Anomalies: A Morphologic and Histologic Study of Affected Like-sexed Twins. Teratology 22:23-35. DOI: 10.1002/tera.1420220105

Table 1. Frequencies of TBC in anatomical and archaeological samples

\begin{tabular}{|c|c|c|c|c|}
\hline \multirow[t]{2}{*}{ Location } & \multirow[t]{2}{*}{ Sample } & \multicolumn{2}{|c|}{ Occurrence of TBC } & \multirow[t]{2}{*}{ References } \\
\hline & & $\mathrm{n}$ & $\%(\mathrm{~N})$ & \\
\hline Italy & Anat & 1 adult & $0.5(200)$ & Morselli, 1890 \\
\hline France, Lion & Anat & 2 adults & $1.3(150)$ & Lucy, 1890 \\
\hline New Caledonia & Anat & 1 adult & $5.0(20)$ & Lucy, 1890 \\
\hline Norway, medieval & Arch & 1 adult & $0.4(243)$ & Barth, 1896 \\
\hline Egypt, Third dynasty & Arch & 1 child & $0.1\left(1100^{*}\right)$ & Schmidt, 1912 \\
\hline Hungary & Anat & 2 adults & $0.4(500 *)$ & Davida, 1913 \\
\hline Baltimore, USA & Anat & $\begin{array}{l}2 \text { fetuses } \\
1 \text { infant }\end{array}$ & $1.8(163 * *)$ & Limson, 1932 \\
\hline South India & Anat & 1 adult & $0.5(202)$ & Ray et al., 2014 \\
\hline Japan, recent & Anat & 1 adult & $0.3\left(349^{*}\right)$ & Kawakubo et al., 2014 \\
\hline Japan, Jomon period & Arch & $\begin{array}{l}3 \text { adults, } \\
2 \text { subadults }\end{array}$ & $6.0(83 *)$ & Kawakubo et al., 2014 \\
\hline $\begin{array}{l}\text { Altai Mountains, } \\
\text { Hunno-Sarmatian } \\
\text { period }\end{array}$ & Arch & 2 adults & $0.6(352 *)$ & Present paper \\
\hline $\begin{array}{l}\text { Altai Mountains, } \\
\text { Scythian period }\end{array}$ & Arch & no & $0.0\left(214^{*}\right)$ & Present paper \\
\hline
\end{tabular}

